\title{
Detection of Cystatin C biomarker for clinical measurement of renal disease by developed ELISA diagnostic kits
}

Renren Jiang ${ }^{1,2,3,4}$, Chao Xu ${ }^{1,3}$, Xiaoli Zhou ${ }^{4}$, Tianhao Wang ${ }^{5^{*}}$ and Gang Yao ${ }^{1,3^{*}}$

\begin{abstract}
Background: Human cystatin C (HCC) is a potential biomarker for tubular damage and impaired renal function. It is difficult to obtain efficient paired monoclonal antibodies against HCC with low molecular to meet the requirements for clinical application The present study was to establish a stable and repeatable measurement for HCC with self-made monoclonal antibodies (McAbs) and Variable domain of heavy chain of heavy-chain antibody (VHHs) increase the sensitivity.

Methods: With hybridoma technology and phage display technology: R-HCC as a screening antigen and N-HCC as the detector for antigens to obtain the specific antibody and established an enzyme-linked immunosorbent assay for human cystatin C using self-made McAbs and VHHs.

Results: We have successfully obtained three McAbs; 5 F2, 4E4, 1 E11 and four VHHs; 3-2, 3-24, 3-33 and 4-5 which were specific for HCC. The measurement of HCC was established with the self-made monoclonal antibodies and VHHs with a high sensitivity the lower limit of detection at $0.5 \mathrm{ng} / \mathrm{ml}$ and the detection range at $0.5 \sim 31.3 \mathrm{ng} / \mathrm{ml}$.

Conclusion: Our data provides a new approach for paired antibody screening and testing of the small molecular biomarker with a single dominant epitope, with the important biological and clinical significance.
\end{abstract}

Keywords: Kidney, Human cystatin C, Renal function, VHH, ELISA

\section{Background}

Renal insufficiency is an important influencing factor for the prognosis of patients with chronic heart failure and more accurate detection of mild renal impairment may improve the risk stratification of the patients, especially with the early impairment of renal function. Circulating levels of creatinine are considered as one of the common readouts to estimate glomerular filtration rate (GFR), an important evaluation index of renal function [1-4]. Circulating levels and endogenous clearance of creatinine are used to clinically detect GFR, while there are many factors influencing the accuracy [5,6]. Some reports of early nephropathy demonstrated that cystain $\mathrm{C}$ has high

\footnotetext{
* Correspondence: tianhao74@hotmail.com; yaogang@sibs.ac.cn

${ }^{5}$ Department of General Practice, Zhongshan Hospital, Fudan University, Shanghai 200433, China

'Key Laboratory for Food Safety Research, Institute for Nutritional Sciences, Shanghai Institutes for Biological Sciences, Chinese Academy of Sciences, Shanghai 200031, China

Full list of author information is available at the end of the article
}

sensitivity and specificity in glomerular filtration rate detection $[7,8]$. Cystatin C, a non-glycosylated protein, is produced continuously by all cells in organs/tissues. It is filtered in the renal glomeruli and completely reabsorbed by the renal tubuli. Alterations of serum cystatin $C$ were considered as an early renal marker in diabetic patients [8-11], cardiovascular diseases kidney transplantation, hyperthyroidism, cancer, or others [12-15]. The detection of cystatin $\mathrm{C}$ was further improved for early diagnosis of serious diseases, with the potential of social and economic significance [16-20].

Cystatin $\mathrm{C}$ as the primary biomarker to estimate GFR and kidney function was measured in serum, plasma, cerebrospinal fluid, or urine [21-26]. The aim of the present study was to establish a new Double-Antibody-Sandwich Enzyme-Linked immunosorbent assay(DAS-ELISA)-based measurement of $\mathrm{HCC}$ with the self-made monoclonal antibody and VHHs by applying the hybridoma technology and phage $\mathrm{VHH}$ display technology, to develop a 
HCC ELISA Test Kit with the highest sensitivity, low cost, and easy operation.

\section{Methods}

\section{Reagents and instruments}

Nucleic acid gel imaging system, nucleic acid electrophoresis apparatus and protein gel electrophoresis apparatus were purchased from Shanghai Tanon company. Microplate reader was purchased from Thermo Fisher Technology Ltd (Shanghai, China). Polyethylene glycol (PEG) was purchased from Merck Co, Mouse typerisotyping panel kit from Bio-RAD Co, and RPMI MEDIEM 1640 medium, penicillin-Streptomycin double antibody solution, newborn calf serum and HEPES from Life Technologies Gibco Co. Hypoxanthine-Aminopterin-Thymidine (HAT) supplemented medium, Hypoxanthine- Thymidine (HT) supplemented medium, Freund's complete or incomplete adjutants were purchased from Sigma. Natural human cystatin $\mathrm{C}(\mathrm{N}-\mathrm{HCC})$ was purchased from Enzo Life Sciences Ltd., Horseradish peroxidase-conjugated goat anti-mouse IgG from Santa Cruz Biotechnology Inc., or Tween-20 and Bovine serum albumin (BSA) from Amresco. BALB/c mice were from Shanghai Institutes for Biological Nutrition, according to the ethical permission approved by the committee of Animal Ethical Evaluation, Chinese Academy of Science. The natural camel single-domain heavy chain antibody library was kindly provided by Dr. Ario de Marco for Italian IFOMIEO center.

\section{Preparation of recombinant $\mathrm{HCC}$}

The total RNA was extracted from renal epithelial $293 \mathrm{~T}$ cells using the TransZol Up RNA kit. The cDNA was synthesized from RNA using the Superscript II reverse transcriptase with OligodT (18) primers, as the template for the PCR reaction. The primers specific for HCC were used to introduce the restriction sites BamH I and Xho I (The primers: 5'-GGATCCAGTCCCGGCAAGCCG-3' and 5'-CCTCGAGCTAGGCGTCCTGACAGGT-3'). PCR products (363 bp) corresponding to HCC fragments and then connected to pEASY-T1 simple T vectors [27-29]. The cloning $\mathrm{T}$ vectors which contain purpose gene and the prokaryotic expression vector pET-32a was digested with BamH I and Xho I twice and dephosphorylated and gel purified before the ligation incubation. The ligation was performed overnight at $16^{\circ} \mathrm{C}$ by T4 DNA ligase. The recombinant plasmids were transformed into Rosetta and the transformants were selected on Luria-Bertani LB agar plates supplemented with $100 \mu \mathrm{g} / \mathrm{ml}$ ampicillin. Single bacterial colony was picked from the transformned plate and verified by PCR, and the positive bacteria were induced to express the target protein. The positive single colonies inoculated (1:100) into $10 \mathrm{ml}$ of LB liquid media containing $100 \mu \mathrm{g} / \mathrm{ml}$ ampicillin as appropriate. Bacterial cultures were incubated at $37^{\circ} \mathrm{C}$ overnight with shaking and then inoculated into $1 \mathrm{~L}$ of fresh antibiotic-containing Luria-Bertani (LB). Isopropyl thio- $\beta$-D-galactose glycoside (IPTG) was added to a final concentration of $0.5 \mathrm{mM}$ to induce protein expression. Bacteria were harvested by centrifugation $\left(8000 \mathrm{r} / \mathrm{min}, 10 \mathrm{~min}, 4^{\circ} \mathrm{C}\right)$ and pellets were re-suspended in $100 \mathrm{ml}$ pre-cold PBS, where phenylmethanesulfonyl fluoride(PMSF) was added at $1 \mathrm{mM}$. Bacterial lysate were centrifuged $\left(12,000 \mathrm{r} / \mathrm{min}, 15 \mathrm{~min}, 4^{\circ} \mathrm{C}\right)$ and the supernatants were transferred to new tubes, while the precipitates were re-suspended in PBS [27,30-33]. An appropriate amount of both the supernatants and suspensions were mixed with an equal volume of $2 \times$ SDS-PAGE (sodium dodecyl sulfate polyacrylamide gel electrophoresis) loading buffer. Expression levels of recombinant RHCC in supernatants and precipitates were analyzed by SDS-PAGE analyses. Bacterial samples that were not induced with IPTG, wild-type Rosetta transformed with pET-32a were used as controls.

The proteins were expressed in an insoluble form as inclusion bodies, where $2 \mathrm{M}$ urea was added, ultrasounded, and hen the lysates were centrifuged $(12,000 \mathrm{r} / \mathrm{min}$, $\left.20 \mathrm{~min}, 4^{\circ} \mathrm{C}\right)$. The supernatants were transferred to dialysis bags in PBS and dialyzed overnight at $4^{\circ} \mathrm{C}$ thrice. The protein solution was dialyzed at the renaturation of His-R-HCC more than $80 \%$ (wt/wt). The Ni-NTA agarose (Qiagen) was used to purify His-R-HCC according to the manufacturer's instructions. Two $\mathrm{ml}$ of Ni-NTA agarose pre-equilibrated with the lysis buffer, including $50 \mathrm{mM} \mathrm{NaH}_{2} \mathrm{PO}_{4}, 300 \mathrm{mM} \mathrm{NaCl}, 10 \mathrm{mM}$ imidazole, $\mathrm{PH}$ 8.0 , was added to the supernatant and gently mixed at $4^{\circ} \mathrm{C}$ for $1 \mathrm{~h}$. The lysate agarose mixture was loaded to the column and washed with the buffer, including $50 \mathrm{mM}$ $\mathrm{NaH}_{2} \mathrm{PO}$, $300 \mathrm{mM} \mathrm{NaCl}$, and $0.05 \%$ (v/v) Tween 20, at $\mathrm{pH}$ 8.0, by the stepwise addition of graduate imidazole concentrations at $20 \mathrm{mM}, 50 \mathrm{mM}, 100 \mathrm{mM}, 200 \mathrm{mM}$, or $500 \mathrm{mM}$, respectively. The protein was eluted using $10 \mathrm{ml}$ of elution buffer with $50 \mathrm{mM} \mathrm{NaH}{ }_{2} \mathrm{PO}_{4}, 300 \mathrm{mM} \mathrm{NaCl}$, $250 \mathrm{mM}$ imidazole at $\mathrm{pH}$ 8.0. Concentrations of purified recombinant proteins were determined by the Bradford assay [30]. His-tagged proteins were digested by thrombin and then the ultrafiltration concentrate was analyzed by SDS-PAGE analyses and Western blot.

\section{Mouse immunization and evaluation of anti R-HCC sera}

Four BALB/c female mice (6-8 weeks old) were immunized with R-HCC by intraperitoneal injections of $100 \mu \mathrm{L}$ at the concentration of $1 \mathrm{~g} / \mathrm{L}$ of R-HCC and $100 \mu \mathrm{L}$ of Freund's adjuvant. The first doses contained complete Freund's adjuvant, and subsequent doses were given a 3-weeks interval using incomplete Freund's adjuvant. Blood samples were collected one week after the fourth injection, and the titer and specificity of antibody response were determined with indirect ELISA $[34,35]$. 


\section{Cell fusion and hybridoma selection and cloning}

Murine myeloma cells were cultured in high-glucose Dulbecco's minimal Eagle's medium (DMEM) supplemented with $20 \%(\mathrm{v} / \mathrm{v}) \mathrm{FBS}$ and $1 \%(\mathrm{wt} / \mathrm{vol})$ penicillinstreptomycin. Cell fusion procedures were carried out according to the protocols of the Clonal Cell- $\mathrm{HY}^{\mathrm{mm}}$ kit. Mouse spleen lymphocytes were mixed with the myeloma cells at the ratio of 5:1 using $1 \mathrm{ml}$ of PEG 4000 . The fused cells were then transferred into a tissue culture plate containing the methycellulose-based selection medium and incubated. The individual hybridoma clones in the semisolid medium were transferred into a 96-well plate about 12 days after the cell fusion. The supernatants were collected when hybridoma cells were grown to approximately $10-20 \%(\mathrm{v} / \mathrm{v})$, and initial screening was performed using indirect ELISA. The screen yielded positive hybridoma cells, which were subsequently sub-cloned thrice by the limiting dilution. Aliquots of first hybridomas and the clones were cryopreserved at several stages during the development.

\section{Purification and characterization of monoclonal antibodies (McAbs)}

Female $\mathrm{BALB} / \mathrm{c}$ mice were intraperitoneally injected with $10^{6}$ hybridoma cells 7 days after intraperitoneal injection with $0.5 \mathrm{ml}$ of liquid olefin. After 14 days, ascites fluid was collected 14 days after the injection with cells and centrifugated at $4000 \mathrm{r} / \mathrm{min}$ for $15 \mathrm{~min}$. McAbs were purified from mouse ascites by ammonium sulfate precipitation followed by affinity chromatography on a protein $\mathrm{G}$ column [30,34-37]. Classes and subclasses of McAbs were identified by mouse monoclonal antibody isotyping reagents (Sigma-Aldrich) following the manufacturer's instructions [33].

\section{Determination of McAbs Affinity}

The affinity constants of McAbs were detected after sample preparation, chip surface pretreatment, sample injection, regeneration, and data analysis. Three $\mu \mathrm{g}$ of natural Human cystatin $\mathrm{C}(\mathrm{N}-\mathrm{HCC})$ and $0.05 \mathrm{M}$ PBS at 7.4 was prepared and filtered. Our pilot experiments showed that the isoelectric point of $9.0 \mathrm{HCC}$ was bonded to the surface of CM5 chip in $\mathrm{HCl}$-glycine buffer at $\mathrm{pH}=4.5$. Three $\mu \mathrm{g}$ $\mathrm{HCC}$ was dissolved in 200ul of $\mathrm{HCl}$-glycine buffer to be fully integrated on the CM5 sensor, and then equilibrated with PBS overnight. The chip was regenerated and then finished, followed by data analysis.

\section{Selection of phage displayed VHHs}

$\mathrm{R}-\mathrm{HCC}$ was coated overnight at $4^{\circ} \mathrm{C}$ in $4 \mathrm{ml}$ NuncImmuno $^{\text {Tw }}$ or Maxisorp ${ }^{\text {tw }}$ tubes at a concentration of $30 \mu \mathrm{g} /$ $\mathrm{ml}$ using $50 \mathrm{mM}$ sodium carbonate buffer thrice before the addition of $3 \times 10^{15}$ phages for the first round of panning after the blocking. Tubes were washed 10 times with
PBS $0.05 \%$ Tween and PBS after 30 min rocking and 90 min standing upright at room temperature, and bound phages were eluted with $10 \mathrm{mM} \mathrm{HCl}, \mathrm{pH}$ 2.0. Eluted phages were neutralized by Tris- $\mathrm{HCl}, \mathrm{pH} 8.0$ and then used to infect TG1 cells at $37^{\circ} \mathrm{C}$ for $40 \mathrm{~min}$. Infected cells were harvested by centrifugation and The new sublibrary of phages was resuspended, titrated, and used in the second round of panning $[38,39]$. The procedure was repeated and the enrichment of the phage sublibrary obtained was calculated as the ratio of output/input phages.

\section{Screening of VHHs by ELISA}

Individual colonies from the dilution series were tested for antigen binding by phage ELISA [38,39]. Tubes containing $1 \mathrm{ml}$ of $2 \times$ TY medium were inoculated with $10 \mu \mathrm{l}$ of the overnight culture. After then, $2 \times 10^{12} \mathrm{KM} 13$ helper phages were added, mixed, and incubated for $1 \mathrm{~h}$. Discard supernatant and resuspend pellets in $5 \mathrm{ml}$ of $2 \times$ TY medium, incubated for about $18 \mathrm{~h}$, and then separated and transferred. The phage clones were tested as described previously [34,39]. Maxisorp 96-well plates (Nunc) were coated with $\mathrm{HCC}$ and added the antigen at $1 \mu \mathrm{g} / \mathrm{ml}$. Plates were washed with PBST and treated with anti-M13 McAb HRP conjugated for $1 \mathrm{~h}$ at $37^{\circ} \mathrm{C}$, and added with $100 \mu \mathrm{l}$ of TMB solution after PBST washing. Plats were analysed at $450 \mathrm{~nm}$ in a microplate reader. Clones with an absorbance value highest were considered positive and the sequences analyzed to identify unique binders.

\section{Purification and characterization of $\mathrm{VHHs}$}

Clones with unique sequence were subcloned into pET28 a vector to obtain His-tagged recombinant VHH binders after transformation into Rosetta competent cells. The supernatant was purified by nickel column affinity chromatography directly $[30,39]$. The purity of the VHH solutions was confirmed by $12 \%$ SDS gel electrophoresis and coomassie blue staining. The property of the purified $\mathrm{VHH}$ was determined by ELISA and Western Blotting.

\section{Determination of VHHs' Affinity}

The affinity of VHHs was determined as described previously $[34,39]$. Plates were coated with N-HCC after blocking and washing. The antibody solution at concentrations below dissociation constant $(\mathrm{Kd}), 0.5 \mathrm{nM}$ was incubated with increasing concentrations of R-HCC from $0.1 \mathrm{nM}$ to $1 \mu \mathrm{M}$. N-HCC-coated plates were added by $10 \mu \mathrm{l}$ of the reaction mixtures, washed with $\mathrm{PBST}$, and added with $100 \mu \mathrm{l}$ of TMB solution for the readout at $450 \mathrm{~nm}$.

\section{The establishment of DAS-ELISA}

The optimized concentrations of HCC paired antibody with McAb 5 F2 and 1E11, or phage displayed monoclonal VHHS P-3-2, P-3-24, P-3-33, and P-4-5, were determined 


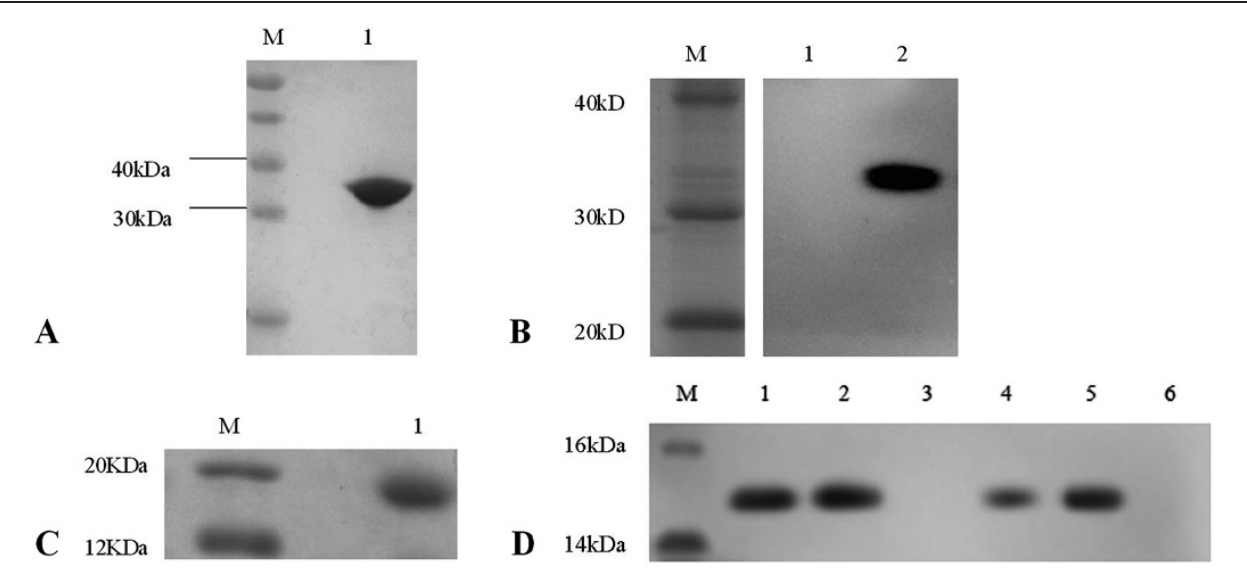

Figure 1 Analysis of the His-tagged R-HCC and VHHs. (A) SDS-PAGE analysis of recombinant His-HCC expressed in Rosetta (DE3), Lane M: the molecular weight markers; Lane1: purified His-tagged R-HCC. (B) Western blot identification of purified His-tagged HCC using mouse anti-His lgG, Lane 1: Control; Lane2: purified His-tagged R-HCC. (C) SDS-PAGE analysis of His-tagged R-HCC digested by thrombin and purified by Ni-NTA, Lane M: the molecular weight markers; Lane1: purified R-HCC. (D) Western blot analysis of purified VHH using mouse anti-His IgG, Lane M: the molecular weight markers; Lane1: purified VHH 3-2; Lane2: purified VHH 3-24; Lane 3: purified VHH 3-30; Lane 4: purified VHH 3-33; Lane 5: purified VHH 4-5; Lane 6: purified VHH 4-8.

by sandwich ELISA. McAbs at $5 \mu \mathrm{g} / \mathrm{ml}$ was added and the absorbance at $450 \mathrm{~nm}$ was measured.

\section{Assay optimization}

The concentration of the coating conjugates with McAbs and $\mathrm{VHH}$ phages was optimized by orthogonal test titration. The capture antibody coated concentrations at 10.0, $5.0,2.5,1.0,0.5,0.2$, and $0.1 \mu \mathrm{g} / \mathrm{ml}$ were used and the incubation concentrations of HCC antigen solution were $20 \mathrm{ng} /$ ml. HRP-antibody solutions were diluted to 100, 200, 500, 1000, 2000, and 4000. The one with the OD450nm value closest to 1.0 was selected as the optimal detection concentration and for further assay development.

\section{Determination of assay properties}

The properties of the developed assay, e.g. linear range, sensitivity, accuracy and precision, were validated. The linear range and sensitivity was determined according to the making of the standard curve. The HCC standard solution was diluted into $62.5,31.3,15.6,7.8,3.9,2.0$, $1.0,0.5,0.2$, and $0 \mathrm{ng} / \mathrm{ml}$, respectively. The standard curve was made using the screened 5 F2-P-3-2 detection kit to detect HCC concentrations. The accuracy of the kit was assayed and calculated by adding HCC to a 5 -fold diluted preparation the urine or serum at standard concentrations, and detecting the recovery of HCC. The concentration of HCC in serum samples was also measured by the turbidimetric immunoassay as the reference. The concentration of HCC in serum samples measured by the commercialized kit was $0.63 \mu \mathrm{g} / \mathrm{ml}$, while the DAS-ELISA could detect the serum levels of $10,25,50$, $100,250,500$, and 1000 fold dilution. The precision of the DAS-ELISA was calculated with the intra-variability at 30 ,
20, 10, or $5 \mathrm{ng} / \mathrm{ml}$ of $\mathrm{HCC}$ sample solution for 10 times and the coefficient of variation $(\mathrm{CV})$ was used to represent the precision.

\section{Results}

The gene encoding HCC construct prokaryotic expression vector Pet-32a-HCC was cloned and expressed in prokaryotic system. The Figure 1A,B demonstrated the protein expression in insoluble inclusion bodies about $80 \%$. R-HCC was obtained at a concentration of $2.377 \mathrm{mg} / \mathrm{ml}$ and the molecular weight of $17 \mathrm{KD}$, of which the purity was more than 95\% (Figure 1C) for McAbs and VHHs. Table 1 shows the titer of sera from mice, of which two mice were more suitable as a mouse hybridoma fusion after four injections of R-HCC.

Of hybridoma McAbs, McAbs 5 F2, 4E4, or 1E11 had high affinity with the coefficients at $2.258^{-9}, 2.975^{-8}$, or $3.622^{-9}$, respectively. The antibody heavy chain is $\gamma$ chain subclasses (IgG1), while light chain subclasses are $\mathrm{\kappa}$ chains (Table 2). The steric orthe same decision epitopes of HCC was identified in those McAbs.

Ten monoclonal colonies with the highest absorptiometry were picked from the third round and the fourth

Table 1 Detection of mouse serum antibody titers by ELISA kit

\begin{tabular}{cc}
\hline Number of mice & Titer \\
\hline$\# 1$ & 128,000 \\
$\# 2$ & 256,000 \\
$\# 3$ & 128,000 \\
$\# 4$ & 256,000 \\
\hline
\end{tabular}


Table 2 Characteristics of the anti-HCC McAbs

\begin{tabular}{ccc}
\hline \multicolumn{3}{c}{ The cell culture supernatant of HCC McAbs } \\
\hline Number of clones & Titer (OD450 \pm SD) & Antibody subtypes \\
\hline 5 F2 & $2.513 \pm 0.179$ & $\lg \mathrm{G} 1, \mathrm{~K}$ \\
$4 \mathrm{E} 4$ & $2.634 \pm 0.087$ & $\operatorname{lgG} 1, \mathrm{~K}$ \\
$1 \mathrm{E} 11$ & $2.426 \pm 0.081$ & $\lg \mathrm{G} 1, \mathrm{~K}$ \\
\hline
\end{tabular}

$1 \times 10^{6}$ of each hybridoma, in $10 \mathrm{ml}$ medium for 2 days, the supernatant was detected directly by ELISA. Data shown in the Table are the mean value of three independent experiments.

round respectively. Six different sequences numbered $3-$ 2, 3-24, 3-30, 3-33, numbered 4-5, 4-8, were obtained, respectively, as shown in Table 3 . The $\mathrm{VHH}$ genes were expressed in the prokaryotic system and purified. $\mathrm{VHH}$ 3-2, 3-24, 3-33, 4-5 could recognize the N-HCC specifically, with the highest affinity for 3-2 (Figure 2A), while VHH 3-30, 4-8 did not (Figure 1D).

The paired results by sandwich ELISA between McAbs 5 F2, 4E4, or 1E11 were negative. The paired results between McAbs and VHHs (phages) demonstrated that McAb 5 F2 and VHH 3-2, 4-5 (VHH phages P-3-2 and P-4-5) were paired to detect $\mathrm{HCC}$, and showed optimal effects (Figure 2B). The optimal coating concentration of 5 F2 and the optimal detection dilution of P-3-2 were $5 \mu \mathrm{g} / \mathrm{ml}$ and 1000 times. DAS-ELISA for $\mathrm{HCC}$ was established with the self-made McAbs and VHHs. The prepared McAbs 5 F2 and VHH phages P-3-2 or P-4-5 were applied for the development of the measurement. The optimal effect was achieved with the minimum detection of $0.5 \mathrm{ng} / \mathrm{ml}$ and the linear range of $0.5 \sim 30 \mathrm{ng} / \mathrm{ml}$. The accuracy measured by adding $\mathrm{HCC}$ to the urine was listed in Table 4, and the precision measured by adding HCC to serum was shown in Figure 2C,D.

\section{Discussion}

Cystain C, a 120 amino acid peptide chain with approximate $13 \mathrm{KD}$, belongs to the family of papain-like cysteine proteases and has the biological role in the extracellular inhibition of Cathepsins. Cystain $\mathrm{C}$ is constantly and largely produced filtered from the glomerular membrane, and then completely reabsorbed from the proximal tubular cells. It has been considered as a biomarker candidate of renal function, although it is difficult to take the paired antibodies by hybridoma technology [40]. Diagnostic kits of cystatin $\mathrm{C}$ commercially available are mainly based on the traditional monoclonal antibody to hardly meet requirements of the clinical application. The present study developed a new way to detect human serum cystatin $\mathrm{C}$ with high sensitivity and specificity through the combination of hybridoma technology and phage display technology.

With the advantage of phage display it is easier than the traditional methods to get the paired antibody for detection of $\mathrm{HCC}$ and it provides a new strategy for the detection of HCC and other small molecules. Using R-HCC as a screening antigen and $\mathrm{N}-\mathrm{HCC}$ as the detection of antigens, we successfully obtained McAbs and VHHs against $\mathrm{N}$-HCC with high affinity. The optimal effect can be achieved with the detectable minimum of $0.5 \mathrm{ng} / \mathrm{ml}$ and the detecting linear range of $0.5 \sim 30 \mathrm{ng} / \mathrm{ml}$, through continuous optimization of conditions. The developed ELISA kit can be used to quantitative detection of HCC in human urine and human serum with the CV precision $<15 \%$. Such pairing can be used for other HCC quantitative measurements, such as colloidal gold strip or latex particle turbidimetric immunoassay method.

$\mathrm{HCC}$ can be stable at room temperature for 2 days, 0 $20^{\circ} \mathrm{C}$ for 7 days, or $-80^{\circ} \mathrm{C}$ for 6 months, without the

Table 3 Selection of VHH antibodies against HCC

\begin{tabular}{|c|c|c|c|c|}
\hline Number of clone & FR1 & CDR1 & FR2 & CDR2 \\
\hline $3-2$ & MADVQLQASGGGLVQAGGSLRLSCAAS & GSIVSIND & MGWYRQAPGKQRDLVAL & ITRGGNT \\
\hline $3-24$ & MADVQLQASGGGLVQPGGSLRLSCAVS & GTNFRLND & MAWYRQPPEKRRELVAL & ITGGGNT \\
\hline $3-30$ & MADVQLQASGGGLVQAGGSLRLSCAAS & GSIASIHD & MGWYRQTPGKQRDLVAL & ITRGGNT \\
\hline $3-33$ & MAEVQLQASGGGLVQPGGSLRLSCAAS & RMVIRTFSGAD & MGWYRQISRNQRELVAL & ITSGGNT \\
\hline 4-5 & MAEVQLQASGGGLVQPGGSLRLSCAA & RMVFSTFSGAD & MGWYRQISGNQRELVAL & ITSGGNT \\
\hline $4-8$ & MAEVQLQASGGGLVQPGGSLRLSCAAS & GSIFSIND & MGWYRQAPGKQRELVAF & ITRGGNTH \\
\hline Number of clone & \multicolumn{2}{|l|}{ FR3 } & CDR3 & FR4 \\
\hline $3-2$ & \multicolumn{2}{|c|}{ NYADSVKGRFTISRDNAKSTVYLQMNNLKPEDTAVYYC } & ATLTRPAYW & GQGTLVTVSSGR \\
\hline $3-24$ & \multicolumn{2}{|c|}{ SYADSVKDRFTISRDNIQRTLYLQMNSLKPEDTAVYYC } & TTQRSGRQYW & GKGTHVTVSSGR \\
\hline $3-30$ & \multicolumn{2}{|c|}{ NYADSVKGRFTISRDNAKSTVYLQMNSLKPEDTAVYYC } & ATLTRPAYW & GQGTLVTVSSGR \\
\hline $3-33$ & \multicolumn{2}{|c|}{ NYTDSVKGRFTISRDNAKGTLYLQMSNLKPEDTAHYYC } & AKISFTGPHRW & GQGTQVTVSSGR \\
\hline 4-5 & \multicolumn{2}{|c|}{ NYTDSVKGRFTISRDNAKGTLYLQMSSLKPEDTAHYYC } & AKISRTTPHYW & GQGTQVTVSSGR \\
\hline 4-8 & \multicolumn{2}{|c|}{ HYADSAKGRFTISRDNAKNTLYLQMNSLKPEDTAVYYC } & NTVNTRTRSW & GQGTQVTVSSGR \\
\hline
\end{tabular}

Amino acid sequences of the diverse binders selected after panning. FR (framework region) and CDR (complementarity determining region) were deduced according to Ana Monegal (Ana Monegal, 2009). Each VHH contains 4 FR and 3 CDR. 


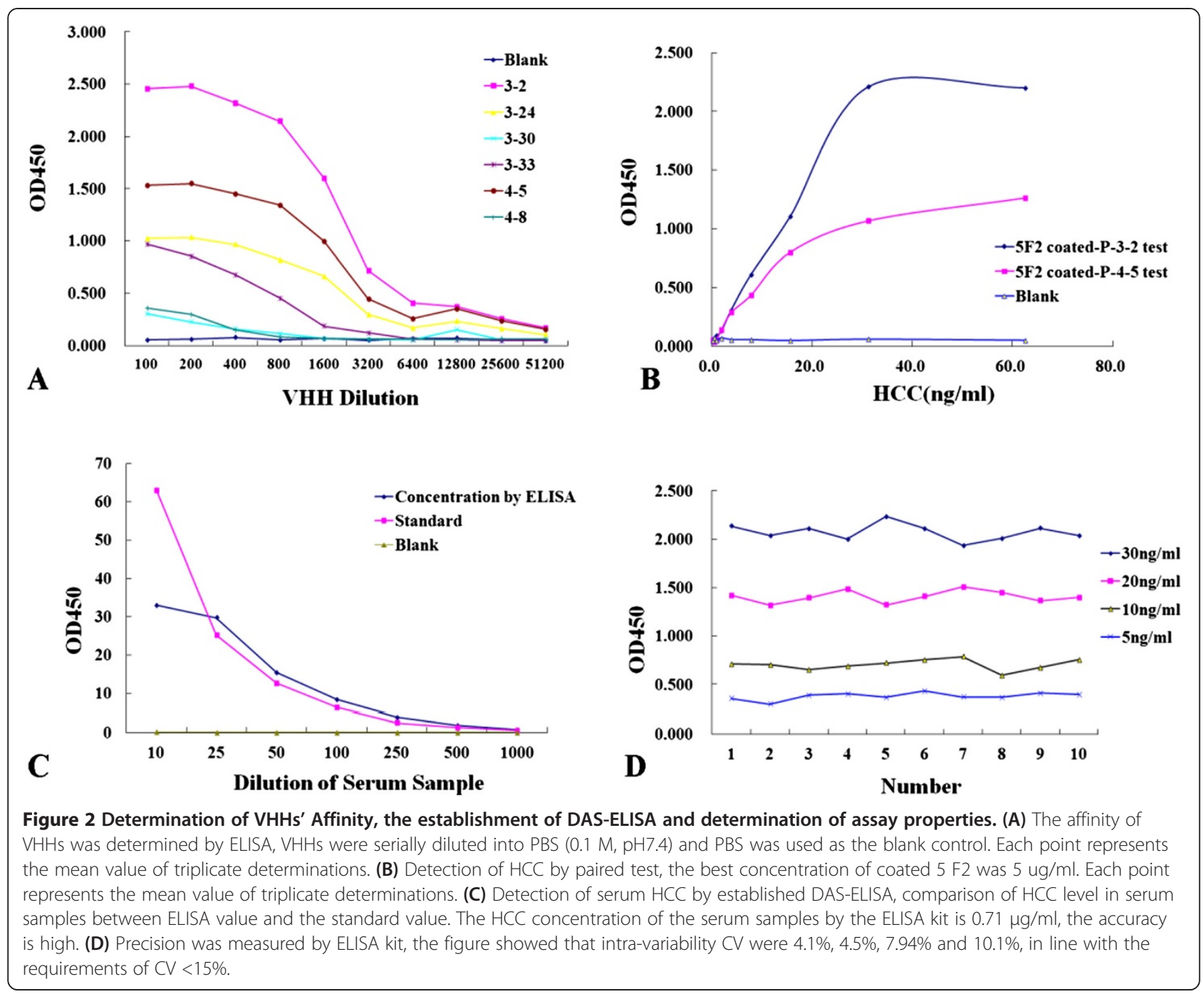

Table 4 Recovery of HCC in spiked urine samples by ELISA kit

\begin{tabular}{cccccc}
\hline $\begin{array}{c}\text { Standard } \\
\text { (ng/ml) }\end{array}$ & OD450 & $\begin{array}{c}\text { Added HCC } \\
\text { (ng/ml) }\end{array}$ & OD450 & $\begin{array}{c}\text { Detected } \\
\text { HCC (ng/ml) }\end{array}$ & Recovery \\
\hline 0 & 0.052 & 0 & 0.097 & 1.36 & - \\
1 & 0.070 & 1 & 0.171 & 2.40 & $105.60 \%$ \\
2 & 0.137 & 2 & 0.249 & 3.50 & $107.20 \%$ \\
5 & 0.376 & 5 & 0.434 & 6.10 & $95.10 \%$ \\
10 & 0.690 & 10 & 0.840 & 11.80 & $104.40 \%$ \\
25 & 1.812 & 25 & 1.937 & 27.20 & $103.40 \%$ \\
30 & 2.201 & 30 & 2.113 & 29.68 & $94.40 \%$ \\
\hline
\end{tabular}

The accuracy of HCC detection kit is $94.8 \%{ }^{1}$ from the data of the table.

${ }^{1}$ Accuracy $=1-\{(105.6 \%-1)+(107.2 \%-1)+(1-95.1 \%)+(104.4 \%-1)+(103.4 \%-1)+$

$(1-94.4 \%)\} / 6$.

${ }^{2}=\mathbf{C}($ control), " $\mathbf{C}$ " means concentration

${ }^{3}$ Recovery $=\{\mathbf{C}($ Detected HCC) $-\mathbf{C}($ control $)\} / \mathbf{C}($ Standard $)$. influences from repeated freezing and thawing. The present study confirmed the reliability and authenticity of the HCC determination, so further improvements of HCC measurements can lead to potential social and economic significance. The combination of the hybridoma technique and phage display technology for screening of paired antibodies provides a new solution, with great biological and clinical significance. The cystain $C$ as a biochemical marker or predictor of GFR offers the greater sensitivity in detecting an abnormal GFR [41,42]. The present study provides the new measurement of GFR to monitor the occurrence and progress of renal diseases. The further works on the application of the clinical measurement of renal disease and other diseases are needed [43-45].

\section{Conclusions}

The present study developed and validated a new measurement of HCC as a biomarker for clinical measurement of 
renal diseases, and established DAS-ELISA for HCC with the self-made McAbs and VHHs by applying the hybridoma technology and phage VHH display technology with high sensitivity.

\section{Abbreviations}

CV: Coefficient of variation; DAS-ELISA: Double-antibody-sandwich enzyme-linked immunosorbent assay; GFR: Glomerular filtration rate: HAT: Hypoxanthine-aminopterin-thymidine supplemented medium; HT: Hypoxanthine-thymidine supplemented medium; IPTG: Isopropyl thio- $\beta$-D-galactose glycoside; Kd: Dissociation constant; LB: Luria-Bertani: McAb: Monoclonal antibody; MW: Molecular weight; N-HCC: Natural human cystatin C; OD: Optical density; PEG: Polyethylene glycol;

PMSF: Phenylmethanesulfonyl fluoride; R-HCC: Recombinant Human cystatin C; SDS-PAGE: sodium dodecyl sulfate polyacrylamide gel electrophoresis; $\mathrm{VHH}$ : Variable domain of heavy chain of heavy-chain antibody.

\section{Competing interests}

The authors declare that they have no competing interests.

\section{Authors' contributions}

All authors participated in the design, interpretation of the studies and analysis of the data and review of the manuscript. RRJ and CX performed and participated in analysis of laboratory experiments data. GY, XLZ and THW provided administrative support and funded experiments. RRJ and CX designed and coordinated the study and drafted the manuscript. All authors have contributed and approved the final manuscript.

\section{Acknowledgements}

This study was supported by grants from the Ministry of Science and Technology of China (2011BAZ0319814 and 2012BAK01B00); the key project of science and technology of Shanghai Agriculture Committee (Shanghai agricultureal science (2012)2-7).

\section{Author details}

'Key Laboratory for Food Safety Research, Institute for Nutritional Sciences, Shanghai Institutes for Biological Sciences, Chinese Academy of Sciences, Shanghai 200031, China. ${ }^{2}$ Shanghai Normal University College of Life \& Environmental Science, Shanghai 200234, China. ${ }^{3}$ Key Laboratory for Food Safety Risk Assessment, Ministry of Health, Beijing 100021, China. ${ }^{4}$ School of Perfume and Aroma Technology, Shanghai Institute of Technology, Shanghai 201418, China. ${ }^{5}$ Department of General Practice, Zhongshan Hospital, Fudan University, Shanghai 200433, China.

\section{Received: 26 January 2014 Accepted: 7 June 2014}

Published: 12 September 2014

\section{References}

1. Naruse H, Ishii J, Kawai T, Hattori K, Ishikawa M, Okumura M, Kan S, Nakano T, Matsui S, Nomura M, Hishida H, Ozaki Y: Cystatin C in acute heart failure without advanced renal impairment. Am J Med 2009, 122:566-573.

2. Hollenberg NK: Renal function in the patient with hypertension. Med Clin North Am 2004, 88(1):131-140.

3. Yildiz G, Mağden K, Abdulkerim Y, Ozcicek F, Hur E, Candan F: Glomerular filtration rate: which method should we measure in daily clinical practice? Minerva Med 2013, 104(6):613-653.

4. Schnermann J, Oppermann M, Huang Y: Nephron filtration rate and proximal tubular fluid reabsorption in the Akita mouse model of type I diabetes mellitus. F1000Res 2013, 2:83-93.

5. Praught ML, Shlipak MG: Are small changes in serum creatinine an important risk factor? Curr Opin Nephrol Hypertens 2005, 14(3):265-270.

6. Bojan M, Lopez-Lopez V, Pouard P, Falissard B, Journois D: Limitations of early serum creatinine variations for the assessment of kidney injury in neonates and infants with cardiac surgery. PLoS One 2013, 8(11):e79308-e79317.

7. Grubb A, Simonsen O, Sturfelt G, Truedsson L, Thysell H: Serum concentration of cystatin C, factor D and beta 2-microglobulin as a measure of glomerular filtration rate. Acta Med Scand 1985, 218(5):499-503.

8. Lopes MB, Araújo LQ, Passos MT, Nishida SK, Kirsztajn GM, Gendoroglo MS, Sesso RC: Estimation of glomerular filtration rate from serum creatinine and cystatin C in octogenarians and nonagenarians. BMC Nephrol 2013, 14(1):265-273.

9. Simonsen O, Grubb A, Thysell H: The blood serum concentration of cystatin C (gamma-trace) as a measure of the glomerular filtration rate. Scand J Clin Lab Invest 1985, 45(2):97-101.

10. Woodson BW, Wang L, Mandava S, Lee BR: Urinary Cystatin C and NGAL as early biomarkers for assessment of renal ischemia-reperfusion injury: a serum marker to replace creatinine? J Endourol 2013, 27:1510-1515.

11. Vega A, de Vinuesa García S, Goicoechea M, Verdalles U, Martínez-Pueyo ML, Chacón A, Quiroga B, Luño J: Evaluation of methods based on creatinine and cystatin $C$ to estimate glomerular filtration rate in chronic kidney disease. Int Urol Nephrol 2013, 10:7-13.

12. Svensson-Färbom $P$, Ohlson Andersson $M$, Almgren $P$, Hedblad $B$, Engström G, Persson M, Christensson A, Melander O: Cystatin C identifies cardiovascular risk better than creatinine-based estimates of glomerular filtration in middle-aged individuals without a history of cardiovascular disease. J Intern Med 2013, 275(5):506-521.

13. O'Seaghdha CM, Tin A, Yang Q, Katz R, Liu Y, Harris T, Astor B, Coresh J, Fox CS, Kao WH, Shlipak MG: Association of a Cystatin C gene variant with Cystatin C levels, CKD, and risk of incident cardiovasculardisease and mortality. Am J Kidney Dis 2013, 63(1):4-6.

14. Jayagopal V, Keevil BG, Atkin SL, Jennings PE, Kilpatrick ES: Paradoxical changes in cystatin $C$ and serum creatinine in patients with hypo- and hyperthyroidism. Clin Chem 2003, 49(4):680-701.

15. Ohara G, Miyazaki K, Kurishima K, Kagohashi K, Ishikawa H, Satoh H, Hizawa N: Serum levels of cystatin C in elderly lung cancer patients. Oncol Lett 2012, 3(2):303-306.

16. Sekizuka H, Akashi YJ, Kawasaki K, Yamauchi M, Musha H: Cystatin C: a better marker to detect coronary artery sclerosis. J Cardiol 2009, 54(3):359-367.

17. Sokol JP, Schiemann WP: Cystatin C antagonizes transforming growth factor beta signaling in normal and cancer cells. Mol Cancer Res 2004, 2(3):183-195.

18. Franco MC, Nagasako SS, Machado PG, Nogueira PC, Pestana JO, Sesso R: Cystatin $C$ and renal function in pediatric kidney transplant recipients. Braz J Med Biol Res 2009, 42(12):1225-1229.

19. ElShafie Al, Elghazali G, Rönnelid J, Venge P: Cystatin C as a marker of immune complex-associated renal impairment in a Sudanese population with visceral leishmaniasis. Am J Trop Med Hyg 2006, 75(5):864-868.

20. Angelidis C, Deftereos S, Giannopoulos G, Anatoliotakis N, Bouras G, Hatzis G, Panagopoulou V, Pyrgakis V, Cleman MW: Cystatin C: an emerging biomarker in cardiovascular disease. Curr Top Med Chem 2013, 13(2):164-179.

21. Flodin M, Larsson A: Performance evaluation of a particleenhanced turbidimetric cystatin C assay on the Abbott ci8200 analyzer. Clin Biochem 2009, 42(9):873-876.

22. Xia $L H$, Bing $X G$, An XT: Grubb A: serum cystatin $C$ assay for the detection of early renal impairment in diabetic patients. J Clin Lab Anal 2004, 18(1):31-35.

23. Hellerstein $S$, Berenbom M, Erwin P, Wilson N, DiMaggio S: The ratio of urinary cystatin $C$ to urinary creatinine for detecting decreased GFR. Pediatr Nephrol 2004, 19(5):521-525.

24. Jaafar A, Seronie-Vivien S, Malard L, Massip P, Chatelut E, Tack I: Urinary cystatin C can improve the renal safety follow-up of tenofovir-treated patients. AIDS 2009, 23(2):257-259.

25. Jeon YK, Kim MR, Huh JE, Mok JY, Song SH, Kim SS, Kim BH, Lee SH, Kim YK, Kim IJ: Cystatin C as an early biomarker of nephropathy in patients with type 2 diabetes. J Korean Med Sci 2011, 26(2):258-263.

26. Ma Y, Li Q, Wang J, Xu Z, Song C, Zhuang R, Yang K, Yang A, Jin B: Cystatin $C$, a novel urinary biomarker for sensitive detection of acute kidney injury during haemorrhagic fever with renal syndrome. Biomarkers 2010, 15(5):410-417.

27. Li F, Yan L, Lai J, Ma C, Gautam M, Fu T: Molecular cloning and mRNA expression profile of sucrose transporter gene BnSUT1C from Brassica napus L. Indian J Exp Biol 2013, 51(12):1130-1136.

28. Ahuja A, Sen A, Yogisharadhya R, Rajak KK, Shivachandra SB: Prokaryotic expression and purification of highly soluble partial Glycoprotein Erns of Indian strain of classical swine fever virus. Indian J Virol 2012, 23(3):397-401.

29. Melcher K: A modular set of prokaryotic and eukaryotic expression vectors. Anal Biochem 2000, 277:109-120.

30. Zhang Y, Wu S, Wang J, Wernike K, LV J, Feng C, Zhang J, Wang C, Deng J, Yuan $X$, Lin X: Expression and purification of the nucleocapsid protein of Schmallenberg virus, and preparation and characterization of a monoclonal antibody against this protein. Protein Expr Purif 2013, 92:1-8. 
31. Feng X, Liu C, Guo J, Song X, Li J, Xu W, Li Z: Recombinant expression, purification, and antimicrobial activity of a novel hybrid antimicrobial peptide LFT33. Appl Microbiol Biotechnol 2012, 95:1191-1198.

32. Rajamohan F, Engstrom CR, Denton TJ, Engen LA, Kourinov I, Uckun FM: High-level expression and purification of biologically active recombinant pokeweed antiviral protein. Protein Expr Purif 1999, 16:359-368.

33. Han K, Xu L, Yan R, Song X, Li X: Molecular cloning, expression and characterization of enolase from adult Haemonchus contortus. Res Vet Sci 2012, 92:259-265.

34. Liu F, Lou Y, Shi X, Wang H, Zhu X: Preparation and characterization of monoclonal antibody specific for copper-chelate complex. J Immunol Methods 2013, 387:228-236.

35. Bai Y, Liu Z, Bi Y, Wang X, Jin Y, Sun L, Wang H, Zhang C, Xu S: Preparation of polyclonal antibodies and development of a direct competitive enzyme-linked immunosorbent assay to detect residues of Phenylethanolamine A in urine samples. J Agric Food Chem 2012, 60:11618-11624

36. Zhang J, Huang B, Yu F, Wei M, Yang G, Fu H, Jin L, Bai L, He X, Lu Z: Production and characterization of polyclonal and monoclonal abs against the RNA-binding protein QKI. Appl Biochem Biotechnol 2011, 164:283-293.

37. Pimpitak U, Putong S, Komolpis K, Petsom A, Palaga T: Development of a monoclonal antibody-based enzyme-linked immunosorbent assay for detection of the furaltadone metabolite, $\mathrm{AMOZ}$, in fortified shrimp samples. Food Chem 2009, 116:785-791.

38. Lee CM, lorno N, Sierro F, Christ D: Selection of human antibody fragments by phage display. Nat Protoc 2007, 2(11):3001-3008.

39. Monegal A, Ami D, Martinelli C, Huang H, Aliprandi M, Capasso P, Francavilla C, Ossolengo G, de Marco A: Immunological applications of single-domain llama recombinant antibodies isolated from a naive library. Protein Eng Des Sel 2009, 22(4):273-280.

40. Sladewska A, Szymańska A, Kordalska M, Lewandowska A, Kołodziejczyk AS, Paraschiv G, Przybylski M, Czaplewska P: Identification of the epitope for anti-cystatin C antibody. J Mol Recognit 2011, 24(4):687-699.

41. Padhy M, Kaushik S, Girish MP, Mohapatra S, Shah S, Koner BC: Serum Neutrophil Gelatinase associated Lipocalin (NGAL) and cystatin C as early predictors of contrast-induced acute kidney injury in patients undergoing percutaneous coronary intervention. Clin Chim Acta 2014, 435:48-52.

42. Sagheb MM, Namazi S, Geramizadeh B, Karimzadeh A, Oghazian MB, Karimzadeh I: Serum cystatin $C$ as a marker of renal function in critically ill patients with normal serum creatinine. Nephro urol Mon 2014, 6(2):e15224-e15230

43. Inker LA, Okparavero A: Cystatin C as a marker of glomerular filtration rate: prospects and limitations. Curr Opin Nephrol Hypertens 2011, 20(6):631-639.

44. Rossi M, Campbell K, Johnson DW, Stanton T, Haluska BA, Hawley CM, Dimeski G, Mcwhinney BC, Ungerer Jacobus PJ, Kaisar OM, Isbel NM: Uremic Toxin Development in Living Kidney Donors: A Longitudinal Study. Transplantation 2014, 97(5):548-554.

45. Shlipak MG, Mattes MD, Peralta CA: Update on cystatin C: incorporation into clinical practice. Am J Kidney Dis 2013, 62(3):595-603.

\section{doi:10.1186/1479-5876-12-205}

Cite this article as: Jiang et al:: Detection of Cystatin C biomarker for clinical measurement of renal disease by developed ELISA diagnostic kits. Journal of Translational Medicine 2014 12:205.

\section{Submit your next manuscript to BioMed Central and take full advantage of:}

- Convenient online submission

- Thorough peer review

- No space constraints or color figure charges

- Immediate publication on acceptance

- Inclusion in PubMed, CAS, Scopus and Google Scholar

- Research which is freely available for redistribution 